\title{
Gönczy Pál hazánkban 2016-ig megismert földgömbjei
}

\author{
MÁRTON Mátyás - TORONYI Bence
}

DOI: $10.30921 / G K .73 .2021 .4 .1$

Absztrakt: A 19. század neves magyar (vagy magyar származásúnak vélhetó) glóbuszkészitói sorát a Budai Ézsaiás vezette debreceni rézmetszó diákok, Lettány Ferenc, Elekes Ferenc, Nagy Károly, Perczel László, Schirkhuber Móric, Hunfalvy János, Gönczy Pál és Kogutowicz Manó neve fémjelzi. A nevezett glóbuszkészítókkel és munkáikkal az elmúlt években több munka is foglalkozott szakfolyóiratunk hasábjain. Jelen tanulmány - utolsóként e sorban - Gönczy Pál földgömbjeivel ismerteti meg az olvasót. A dolgozat egy három cikkból álló sorozat elsố tagja, amelyben a szerzók a korábbiakhoz hasonlóan - összefoglalják a szakirodalomban megjelent Gönczy-glóbuszokkal kapcsolatos publikációkat, és áttekintik a 2016-ig hazánkban megismert földgömbjeit.

Abstract: The major 19th-century Hungarian globe makers - including those who may be considered Hungarian after their origin - were the copper engraving students of Debrecen led by Ézsaiás Budai, Ferenc Elekes, Ferenc Lettány, Károly Nagy, László Perczel, Móric Schirkhuber, János Hunfalvy, Pál Gönczy and Manó Kogutowicz. The named globe makers and their work have been the subject of several studies in recent years in the columns of our journal. This paper - the last in this row - introduces the reader to the globes of Pál Gönczy. This work is the first in a series of three articles in which the authors - as earlier too - summarize the publications on Gönczy's globes published in the literature, and review his globes known in Hungary until 2016.

Kulcsszavak: magyar nyelvű glóbuszok Prágából és Berlinből, Virtuális Glóbuszok Múzeuma

Keywords: Hungarian-language globes from Prague and Berlin, Virtual Globes Museum

\section{A magyar szakirodalom Gönczy glóbuszairól}

Gönczy Pál [(Hajdú)Szoboszló, 1817. december 26. - Karácsond, 1892. január 10.] neve mint hivaltalnoké (oktatásügyi államtitkár), mint szerkesztőé (a glóbuszok magyarítója), mint szakíróé (több, egyebek mellett a földgömbök használatát magyarázó kiadvány szerzője), vagy mint továbbképzố pedagógusé („előadásokat rendezvén, ... hogy az összegyúlt tanítókat a földgömbbel és használati módjával megismertessem") forrt össze a magyar térképész szakirodalomban. Úgy is, mint a kiegyezést követô idôszak hazai - a kor nemzetközi színvonalának megfelelố - földrajzoktatását megteremtô segédeszközök (fali és kézi térképek, valamint föld- és éggömbök) biztosítója a magyar iskolák számára. Tekintsük át, hogyan emlékeznek meg térképtörténetünk szerzôi errôl a szúkebb szakmai munkásságáról.

Fodor Ferenc [1887-1962] A magyar térképírás címú 1952-1954ben megjelent munkájában ezt olvashatjuk [p. 369.]: „Az abszolutizmus alatt természetesen cseh, német és osztrák földgömbök szivárogtak be a magyar iskolákba, s ez ellen még az önrendelkezési jog visszanyerése után sem lehetett semmit sem tenni egyideig, mert magyar földgömböket senki sem állított elő. Kogutowicz Manó 1896ban fogott hozzá globuszok gyártásához. 1897-ben már örömmel jelentette a Földrajzi Társaság elnöke a közgyúlésen, hogy elkészültek az első 25,5 és $51 \mathrm{~cm}$ átmérôjú földgömbök.

Annál érthetetlenebb, hogy a Gönczy Pál által már elôbb egy »magyarított“ cseh földgömb, "A Föld, magyarul szerkesztette Gönczy Pál. A m. kir. közoktatásügyi minister megrendeléséból kiadta Felkl J. és fia Roztokban Prága mellett« címen mégis megjelenhetett 1897-ben II. kiadásban Berecz Antal átvizsgálásával. Ez az utóbbi $32 \mathrm{~cm}$ átmérójú gömb volt, amelynek hiányosságait jellemzi az, amit a II. kiadásának ismertetésében róla írnak: »Ezen új kiadású földgömbrôl eltüntek mindazok a hiányok, amelyek az elsố kiadást hazai iskolánkban való használatra alkalmatlanná tették." Úgy látszik azonban, hogy sem Gönczy, sem Berecz nem tudtak rajta segíteni, hogy a magyar iskolákban megtû́rhessék, mert 1908-ban a közoktatásügyi miniszter végleg kitiltotta a magyar iskolákból azzal az indoklással, hogy "fogyatékos és elavult a tartalma, valamint a magyar közjogba ütközó hibái “ vannak" (Fodor 1952-1954).

Ambrus-Fallenbüchl Zoltán [19242006] 1964-ben megjelent tanulmányában így ír: [p. 29.]: „A Habsburg-ház és a magyarok közötti 1867-es kiegyezést követôen a magyar iskolákba a Prága melletti roztoki Felkl cégtôl rendeltek állami kezdeményezésre földgömböket. Természetesen ezeken a megírásnak magyarnak kellett lennie. Ezrével készültek a Felkl-gömbök Magyarországra...

A glóbuszok magyar iskolákban való elterjesztéséért Gönczy Pál tett a legtöbbet.

A kiegyezés után államtitkár lett a magyar Közoktatásügyi Minisztériumban, így hatalmában állt az állami iskolák glóbuszkérdését szabályozni. Kiadatott külföldi gömböket magyar felirattal, melyeket a berlini Schotte Kiadó gyártott, és Felklnél is tömegesen jelentetett meg föld- és éggömböket. Ezeken a magyar feliratról ô maga gondoskodott. Két különbözô típusban és mindkettốt 3-féle méretben - 18, 12, és 8 coll, vagyis 47,5 , 31,6 és $21 \mathrm{~cm}$-es átmérôvel - adták ki. Az elsố egyszerú volt. A gömb egy tengelyen körbeforgatható volt, és kicsi stabil talapzaton állt. A másik fajta teljesen felszerelt volt. Háromlábú faállványon állt, a horizontkörön naptárral, a sárgaréz teljes meridiángyúrû́n fokbeosztással. Az aljára iránytūt helyeztek"1 (Ambrus-Fallenbüchl 1964).

\footnotetext{
${ }^{1}$ Az eredeti szöveg fordításáért Márton Juditnak jár köszönet. - MM
} 
Füsi Lajos [1920-1999] 1966-os doktori értekezésében már sokkal szúkszavúbb [p. 17.]: „A kiegyezés után a magyar iskolákba a földgömböt a prágai Felkl cég szállította. Ezeket a gömböket magyar felírással látták el. A magyarítás Hunfalvy János és Gönczy Pál nevéhez fűzôdik. A földgömbök két típusban és háromféle nagyságban (47,5; 31,6 és $21 \mathrm{~cm}$ átméróvel) kerültek forgalomba..." (Füsi 1966).

Klinghammer István 1969-ben írt dolgozatában [p. 210.], majd 1973-as [pp. 43-44.], 1998-as [pp. 97-98.] és 2002-es [p. 9.] munkáiban is - szinte változatlanul - ezt olvashatjuk: „... az 1867. évi kiegyezést követóen... magyar földgömböket sorozatban senki sem állított elô. A kiegyezés után a magyar iskoláknak a prágai Felkl-cég százával szállított magyarított föld- és éggömböket. A külföldi gömböknek magyar felirattal való ellátásáról Gönczy Pál, az Oktatásügyi Minisztérium államtitkára gondoskodott. A gömbök felirata: "A Föld, magyarul szerkesztette Gönczy Pál. A m. kir. közoktatásügyi miniszter megrendeléséből kiadta Felkl János és fia Roztokban Prága mellett." E gömbök két típusban, három különböző nagyságban (8, 12 és 18 coll átmérôvel) kerültek forgalomba. A drágább, teljes felszerelésû glóbusz három falábon állt, a lábak közé egy kompasz volt erôsítve. Tartozéka volt egy fokbeosztásos meridiánkör és horizonti kör naptárral...

Mind Gönczy, mind Hunfalvy gömbjei csak egy kiadásban láttak napvilágot.

A forgalomba hozott glóbuszok elfogytak, elhasználódtak és pótlásukról senki sem gondoskodott. (Egy 1908-ban kiadott közoktatásügyi miniszteri rendelet "fogyatékos és avult tartalma, valamint a magyar közjogba ütközó hibái miatt «a magyar iskolákból kitiltotta a még meglevô darabokat.)" (Klinghammer 1969, 1973, 1998, 2002).

Irmédi-Molnár László [1895-1971] 1971-ben megjelent „Térképalkotás”-a [p. 129.] is csupán érinti a kérdést: „1869-ben a térképszerkesztô Gönczy Pál javasolta, hogy az iskolák felszerelését földgömbökkel egészítsék ki... Különféle nagyságú és felszerelésû́ gömböt készített, illetve fordított magyarra.

Az 1871-es évben Hunfalvy János földgömbjei kiszorították a Gönczyféléket. Gönczy és Hunfalvy gömbjei, miután csak egyszer jelentek meg, $\mathrm{s}$ pótlásukról nem gondoskodtak, teljesen elfogytak, elhasználódtak, és így újra beállt a hiány" (Irmédi-Molnár 1971).

Stegena Lajos [1921-1997] 1980ban megjelent „Térképtörténet”-e még szúkszavúbb: [p. 156.] „Gönczy 1869től iskolai földgömböket szerkesztett" (Stegena 1980).

Papp-Váry Árpád 1983-as munkáját [p. 337.] szó szerint ismétli 2007-ben [p. 409.]: „A kiegyezés után Jan Felkl (1817-1887) cége - a Prága melletti Roztokban - látja el a magyar iskolákat többféle nagyságú föld- és éggömbökkel. A glóbusok feliratait Gönczy Pál, a Közoktatásügyi Minisztérium államtitkára, és Hunfalvy János, az elsố földrajzi egyetemi tanszék professzora magyarította" (Papp-Váry 1983, 2007).

Patay Pálné [1924-2015] 1984ben megjelent cikkében [pp. $457-$ 458.] egy Felk1-Gönczy-féle kombinált glóbuszról - mint az Országos Széchényi Könyvtár Térképtárának új szerzeményérôl - számol be. Ezzel a gömbfajtával korábban a magyar szakirodalomban nem találkoztunk. A két félgömbbé szétnyitható $21,9 \mathrm{~cm}$ átmérôjū földgömb belsejében - azzal közös tengelyre helyezett - $16 \mathrm{~cm}$-es éggömb bújik meg. Az elóbbi, a tartalom alapján 1898 és 1900 közötti, az utóbbi, a kolofon nyomán 1870 elốtti szerkesztésú, s mindkettô egyértelmúen Gönczy-magyarítás. „A kombinált glóbusz összeállítása, ill. a földgömb rajzának elkészítése idején Gönczy Pál már nem élt... A magyar feliratokat tehát egy ugyancsak régibb nyomólemez segítségével nyomták rá az újabb vagy javított földrajzi alapra. Ezzel kapcsolatban még csak azt az érdekességet említjük meg, hogy a monarchia városainak jele mellett csak Budapest, Prága és Lemberg neve van kiírva, Bécsé nincs!" (Patayné 1984).

Horváth Gergely 1986-os tanulmánya „Iskolai földgömbök”-rôl írt elsô részében összefoglalja a már eddig taglalt tényeket, de érdekes adalékokkal is szolgál a Felkl-cégrôl szólva [p. 365.]: „Az elsố földgömbök 1870ben jelentek meg. Gönczy maga írt egy nagyon részletes módszertani útmutatót is használatuk elősegítésére (»Utasítás a földgömb és a tellurium ismertetésére és használatára népiskolai tanítók számára»).

Különösen érdekesek voltak a Felkl-cég által szállított kombinált glóbuszok, azaz olyan gömbök, amelyek egy szétnyitható földgömbből és egy annak belsejében elhelyezkedő éggömbbôl álltak...

Mind a Gönczy-, mind a Hunfalvyféle gömbök több javított kiadást is megértek (jóval Gönczy halála után is), és még a századforduló után is használatosak voltak...

A Felkl-cég mellett Gönczy a berlini Ernst Schotte és Társa kiadóval is kapcsolatba lépett földgömbök szállítása ügyében. E kapcsolatról nagyon keveset tudunk, de hogy létezett, azt néhány fennmaradt gömb bizonyítja ${ }^{2}$. Jelenleg egy 5 és egy 12 collos változat ismert. Feliratuk szerint „A legújabb és legjobb források szerint készített földgömb. Magyarította Gönczy Pál. Kiadja Schotte Ernô és Társa Berlinben”.

„Egyes korabeli források azonban arra is utalnak, hogy a Schottecég Gönczy megrendelésére domborföldgömböket is készített ${ }^{3,4}$ 1872 táján..." (Horváth 1986).

Klinghammer István 1998-ban, könyvében [p. 98.], a már elôbb tôle idézettekhez néhány kiegészítést tesz (amely lényegének 2002-es tanulmányában is helyt ad [p. 9.]):

„Mind Gönczy, mind Hunfalvy gömbjei - egyetlen kivétellel - csak egy kiadásban láttak napvilágot. (A kivételt Gönczy 12 colos gömbje jelentette, amelyet 1897-ben Berecz Antal átvizsgálásával újra kiadtak.) ... Gönczy gömbjeit komoly kritika fogadta. A felvetett hiányosságok súlyát jól jellemzi, ami a második kiadásban megjelent

\footnotetext{
2 Debrecen, Tiszántúli Református Egyházkerület Nagykönyvtára; egy másik példány magántulajdonban (ifj. Bartha Lajos szíves közlése alapján)

3 Kiss Á.: Gönczy Pál életrajza. Budapest, 1888

4 Szinnyei J.: Magyar írók élete és munkái I-XIV. Budapest, 1891-1914
} 
egyetlen gömbjének ismertetésében szerepel: »ezen új kiadású földgömbrôl eltúntek mindazok a hiányok, amelyek az elsố kiadást hazai iskolákban való használatra alkalmatlanná tették«"

Azt is meg kell említeni itt, hogy bár Klinghammer nem beszél könyvében Gönczy berlini kiadású glóbuszairól, de ábrát közöl [p. 97., 127. kép], az alábbi aláíással: „A legújabb és legjobb források szerint készített Földgömb, magyarította Gönczy Pál, kiadja Schotte Ernô és társa Berlinben" (Klinghammer 1998).

Fodor Ferenc 2006-ban kiadott, $A$ magyarföldrajztudomány történetét részletesen tárgyaló, hatalmas elemzó múvében a földrajztanítást szolgáló tankönyvek, taneszközök között szúkszavúan ugyan, de megemlékezik a glóbuszokról is:

„Az abszolutizmus alatt Schirkhuber Móricz piarista tervezett magyar földgömböt, Felkl cseh-osztrák földgömbje után, amely azután nyolc ujjnyi átmérôvel Prágában jelent meg. Ezeket váltotta fel Gönczy Pál földgömbje késóbb (1870), amely azonban szintén Prágában készült, ugyancsak Felklnél” (p. 445.).

„Fizikai földrajzhoz Schneider „Képes atlasz”-át használták, amelyet Gönczy és Hunfalvy fordított magyarra (1881). Földgömböt ugyancsak Gönczy adott ki magyarul 1872ben, ugyancsak idegen eredeti nyomán, s telluriumot és planetáriumot is ugyanazon évben, ezek berlini készítmények voltak" (p. 453.).

Fodor végül könyve életrajzokat bemutató részében Gönczy Pál fontosabb - témánkhoz szorosan kapcsolódó - „földrajzi segédeszközei” között az 1870-es glóbuszt már nem sorolja, csupán a következőket említi: „1872: Utasítás a földgömb és tellurium ismertetésére és használatára népiskolai tanítók számára (Pest); ... 1872: Schotte sima és domború földgömbjei különféle átmérôkkel" (Berlin); ... 1872: Tellurium Planetarium (Berlin)" (p. 585.).

A 2007-ben az Eötvös Loránd Tudományegyetem Térképtudományi és Geoinformatikai Tanszékén létrehozott Virtuális Glóbuszok Múzeuma (2007-) (VGM) számos, addig a szakirodalomból sem ismert „rejtôzködô” glóbuszt tárt folyamatosan a szakmai és az érdeklôdố nagyközönség elé. Jelentôs hányaduk magánszemélyek önzetlen felajánlásának eredményeképpen került napvilágra, akik hozzájárultak gyújteményük féltve ôrzött darabjainak feldolgozásához és a Múzeumban történó bemutatásához. Ezzel párhuzamosan gazdagodhatott, bôvülhetett a térképtörténeti szakirodalom is. Ma 22 Felkl- és 3 Schotteföldgömb található a VGM-ben. Közülük 13 + 3 Gönczy-magyarítás! [2 ezekból nem volt kiállítva 2010-2011ben - lásd alább -, mivel más kiállításokon szerepeltek, vagy később kerültek látókörünkbe. Ezek a kalocsai Fôszékesegyházi Könyvtár 47,4 cm-es (ID 137), valamint az érdi Magyar Földrajzi Múzeum 47,4 cm-es (ID 149) glóbuszai. - A megújuló utóbbit majd következố cikkünkben tárgyaljuk.]

A Plihál Katalin vezetésével és Márton Mátyás közremúködésével szervezett, az Országos Széchényi Könyvtár Térképtára, valamint az ELTE-tanszék közös, a Budavári palotában 2010. október 16. és 2011. március 31. között megrendezett, „Nyomtatott magyar föld- és éggömbök a kezdetektôl napjainkig" címú kiállítása a felsorakoztatott nagyszámú glóbuszával korábbi ismereteink nyilvános bemutatásához jelentôs mértékben járult hozzá, és nem csak a „lappangó" Gönczy-glóbuszok feltárásával (1. ábra) (Plihál et al. 2010-2011).

Lovizer Lilla 2013-ban a Felkl-cég múködésének ismertetése kapcsán tárgyalja a Gönczy- (és a Hunfalvy-) glóbuszokat a magyar földrajzoktatás szemszögébôl. Dolgozatának kéziratában még szerepel egy érdekes összesítés, ami a kinyomtatott cikkben - nyilván terjedelmi okok miatt - már nem jelent meg. Eszerint az OSZK Térképtárában tizenöt különbözô Gönczy által magyarított Felk1glóbuszt azonosítottak „egy nemrég megrendezett földgömbkiállítás kapcsán" (földgömbök: $1 \mathrm{db} 12 \mathrm{~cm}$ Ø; $1 \mathrm{db} 16 \mathrm{~cm} \varnothing ; 7 \mathrm{db} 21 \mathrm{~cm}$ \%; $3 \mathrm{db}$ $32 \mathrm{~cm} \mathrm{Ø;} 1 \mathrm{db} 47 \mathrm{~cm}$ Ø; éggömbök: $1 \mathrm{db} 16 \mathrm{~cm} \mathrm{Ø;} 1 \mathrm{db} 22 \mathrm{~cm} \mathrm{Ø).}$

„Az újabb cégek újabb termékeinek megjelenésével, melyek a földrajzoktatás egyre szaporodó nyelvi követelményeit illetôen is naprakészek voltak, a régebbi névírással dolgozó Felkl-glóbuszok piaci egyeduralma fokozatosan megtört. Egyre inkább elôtérbe kerültek például, az 1870-es évektôl kapható, szintén Gönczy által magyarított, Schotte-féle gömbök vagy a bécsi Hölzel cég termékei, amely már a '90-es években árult glóbuszokat és tellúriumokat, igaz saját földgömbbel $(25 \mathrm{~cm} \emptyset)$ csak a századforduló után jelent meg a piacon5. 1896-ban a Kogutowicz Manó által alapított Magyar Földrajzi Intézetnél is megindult a földgömbgyártás, s ezekkel a csúcsminôségú, államilag támogatott taneszközökkel a Felkl cég termékei már nem tudták tartani a versenyt."

Papp-Váry Árpád ugyancsak 2013 ban megjelent tanulmányában - mintegy kiegészítve az előbb tárgyaltakat -, Ernst Schotte berlini cégének magyar nyelvú földgömbjeivel és (dombor-) térképeivel foglalkozik.

Plihál Katalin 2016-ban megjelent könyvében az eddigi kutatások eredményeit és saját feltáró vizsgálatait összegzố leírásai/megállapításai nyomán a Felkl-cég gyártotta, Gönczy Pál magyarította földgömbökból rendre az alábbiakat ismerteti:

$41 \frac{12}{2}-$ os $(=11,83 \mathrm{~cm})$ [1 : 140000000$]$ 1884-bôl [p. 103.], 6"-os (=15,8 cm) [1 : 81000 000] 1885 után [p. 107.], 8 "-os (=21,7 cm) [1 : 60000000$] 1869$ körül, 1884-ból, 1885-1890 között [p. 110.], 1891-1894 között, 1894 után, 1905-1908 között [p. 111.], 12"-os $(=31,56 \mathrm{~cm})[1: 40000000] 1896$ ból, 1897-ból, 1907-ból [p. 115.], 18”os $(=47,37 \mathrm{~cm}) 1: 27000000] 1869$ bôl és 1888 körül [p. 117.]. A kombinált glóbuszok (föld- és éggömb egyben) említése a 111., 112. (kép) és a 117. oldalon történik.

A Schotte-Gönczy-féle földgömb kevesebb van:

$41 / 2 "$-os $(=11,83 \mathrm{~cm})[1: 140000000]$ 1872-bôl [p. 128.], 9"-os (= 23,4 cm) [1 : 56250 000] 1870-1875 között, 1885-1887 között [p. 129.], 12"-os $(=31,56 \mathrm{~cm})[1: 40000000] 1903-$ 1905 között [p. 129.].

\footnotetext{
5 Wohlschläger, Heide und Dörflinger, Johannes: Österreichische und deutsche Globenhersteller der zweiten Hälfte des 19. und des beginnenden 20. Jahrhunderts. Globusfreund, $\mathrm{Nr}$. 30. 1982. pp. 21-30.
} 
Klinghammer István 2017-ben megjelent dolgozatában - amely egyben Plihál Katalin fentebb idézett könyvének ismertetése és méltatása is -, Gönczy Pál földgömbjeinek ismertetését a témával foglalkozó 1969-es és az azt követô tanulmányaira hagyatkozva mutatja be, függetlenül attól, hogy a Plihál-könyvben több, azóta fellelt glóbusz bemutatására is sor kerül. Klinghammer „két típusban, három különbözó nagyságban, 8, 12 és $18 \mathrm{col}$ (21, 31,6 és 47,4 cm) átmérôvel" forgalomba került glóbuszokról tesz említést, amelyek „-- egyetlen kivétellel - csak egy kiadásban láttak napvilágot”.

\section{Amit a Gönczy- glóbuszokról ma tudni érdemes}

Tekintsük át vázlatosan, elsôsorban a VGM-re támaszkodva - az OSZK kiállításra és Plihál Katalin könyvére utalva - a ma hazánkban ismert Gönczyféle földgömböket. Jelen dolgozatban Gönczy éggömbjeivel nem foglalkozunk, ezekról már korábban jelent meg cikk e folyóirat hasábjain (MártonPlihál 2010). Közöttük az ún. kombinált vagy kettôs glóbusz(ok)ról is szó esett, amely(ek)nél a szétnyitható földgömb belsejében található az éggömb. Mivel azonban - az egyetlen ismert, földgömbbel együtt megmaradt kombinált glóbusz, az OSZK Térképtárából ismert példányának - földgömbjét ott nem tárgyaltuk, rövid ismertetésére ebben a tanulmányban kerül sor. Az OSZK kiállításon szereplô glóbuszokról külön képet nem közlünk (lásd: 1. ábra).

Gönczy múveinek tételes felsorolását több helyen is megtalálhatjuk. Ezek az összegzések - kisebb eltérésektôl eltekintve - megegyeznek. Négy, munkánkhoz konkréten kapcsolódó tételt emelünk ki ezekből Szinnyei (1894, pp. 1364-1365.) nyomán: „23. Földgömb (magyar nyelven.) Prága, 1870. - 32. Utasítás a földgömb és a tellurium ismertetésére és használatára népiskolai tanítók számára, Pest, 1872. (2. bôvített kiadás 1973., 3. bővített kiadás 1886. Ugyanez németúl. Pest, 1873. ruménúl Kozma András ford. Bpest, 1882.) - 35. Schotte sima és domború földgömbjei különféle átmérôkkel.
U.ott, 1872. - 37. Tellurium Planetarium. Berlin, 1872."

Érdekes, hogy Szinnyei az Utasítás elsô kiadását 1872-re, a másodikat 1873-ra teszi! Valójában az elsố kiadás 1871-ben jelent meg Ráth Mórnál, és még a telluriumokkal nem foglalkozik benne Gönczy. Ennek felel meg a címe is: „Utasítás a földgömb ismertetésére és használatára népiskolai tanítók számára”. A 80 oldal azután 108-ra bôvül 1872-ben az „Utasítás a földgömb és a tellurium ismertetésére és használatára népiskolai tanítók számára" címú könyvecskében.

\section{A Felk1-Gönczy-glóbuszok}

Az alábbi rövid, néhány mondatos ismertetésekben a mai legjobb tudásunk szerinti adatok szerepelnek. Ezek értelemszerúen nem mindig egyeznek bármely szerzó korábbi adataival! Az ellentmondásokra külön nem hívjuk fel a figyelmet. A bemutatott glóbuszok részletesebb tartalmi leírása a VGM-ben, illetve Plihál könyvének hivatkozott részében olvasható.

\section{$11,9 \mathrm{~cm}\left(4^{1 / 2}\right.$ bécsi} hüvelyk) átmérôjjú,

1 : $107677000^{6}$ méretarányú domborzati-politikai földgömb. Egyenlítôi kerülete: $37,22 \mathrm{~cm}$.

Kontinenshatárbandos színezésú, elnagyolt lejtốcsíkozásos domborzatrajzú, 1884 után készített glóbusz országhatárokkal és országnevekkel. Greenwichi kezdőmeridián, jó állásban megrajzolt Ekliptika jellemzi. Kolofon: „FÖLDGÖMB. | Kiadtak (!) Felkl J és fia (!)”. A magyar kiadás szerkesztôje Gönczy Pál lehet, mivel a még szóba jöhetô Hunfalvy János, rendszerint a „világtenger” kifejezést használja az „óceán” helyett, illetve az eddig megismert Hunfalvy-kolofonok a FÖLDÜNK ,termékmegjelöléssel” kezdôdnek (VGM ID 46; 1 ábra. 14. kép; Plihál p. 103.).

\footnotetext{
${ }^{6}$ Az egyik legújabb szakirodalmi munkát követve (Novotná 2017) ezerre kerekítve adjuk meg a méretarányszámokat, és közöljük a glóbuszok egyenlítôi kerületét is. A számításoknál használt adatok: a földi Egyenlítô hossza: $4007570400 \mathrm{~cm}, 1$ bécs hüvelyk $($ zoll $)=2,634 \mathrm{~cm}$ (Cartographia Világatlasz, Bp., 2001).
}

\section{$15,8 \mathrm{~cm}$ (6 bécsi} hüvelyk) átmérójú, 1 : 81000000 méretarányú domborzati-politikai földgömb. Egyenlitố kerülete: 49,62 cm.

Országhatárbandos, lejtốcsíkozásos domborzatrajzú, 1905-ben kiadott glóbusz, párhuzamos vonalfonatokkal jelölt tengeráramlásokkal és nyilakkal jelölt áramlásirányokkal, tengermélységadatokkal, transzkontinentális vasútvonalakkal. A kezdómeridián greenwichi, jó állásban megrajzolt Ekliptika jellemzi. Kolofon: „FÖLDGÖMB | Magvarúl (!) szerkesztette | Gönczy Pál" (VGM ID 47; 1. ábra. 22. kép; Plihál p. 107.).

\section{1,7 cm (81/4 bécsi} hüvelyk) átmérôjuú, 1 : 58733000 méretarányú politikai földgömb. Egyenlítôi kerülete: $68,23 \mathrm{~cm}$.

Színes kontinens- és országhatárbandos, 1871-ben (közvetlenül a német egység létrejöttét követően) megjelent glóbusz, amelyen még az szerepel, hogy „Kiadta Felkl János PRÁGÁBAN.” (Felkl 1870-ben a Prága melletti Roztokba tette át székhelyét, és a cég neve pedig „Felkl és fia” lett!) Tengeráramlás-ábrázolás: párhuzamos vonalfonatokkal, nevekkel, áramlásnyilakkal. Tengerhajózási útvonalak. Ferrói kezdômeridián és fordított állásban megrajzolt Ekliptika jellemzi. Kolofon: „A | FÖLD | a legújabb felfedezések nyomán | Magvarúl (!) szerkesztette | Gönczy Pál | a m. kir. közoktatási minister megrendeléseböl. (!) | Kiadta Felkl János | PRÁGÁBAN." (VGM ID 54; 1. ábra. 13. kép; Plihál p. 11. 2. leírás, p. 112. „1861 és 1867 között” feliratú kép).

\section{$21,7 \mathrm{~cm}\left(8^{1 / 4}\right.$ bécsi hüvelyk) átmérôjú,} 1 : 58733000 méretarányú domborzati-politikai földgömb. Egyenlítôi kerülete: $68,23 \mathrm{~cm}$.

Országhatárbandos, lejtốcsíkozásos domborzatrajzú, 1905-ben vagy az után kiadott glóbusz, párhuzamos vonalfonatokkal jelölt tengeráramlás-ábrázolással és nyilakkal jelölt áramlásirányokkal, tengermélységadatokkal, hajózási 

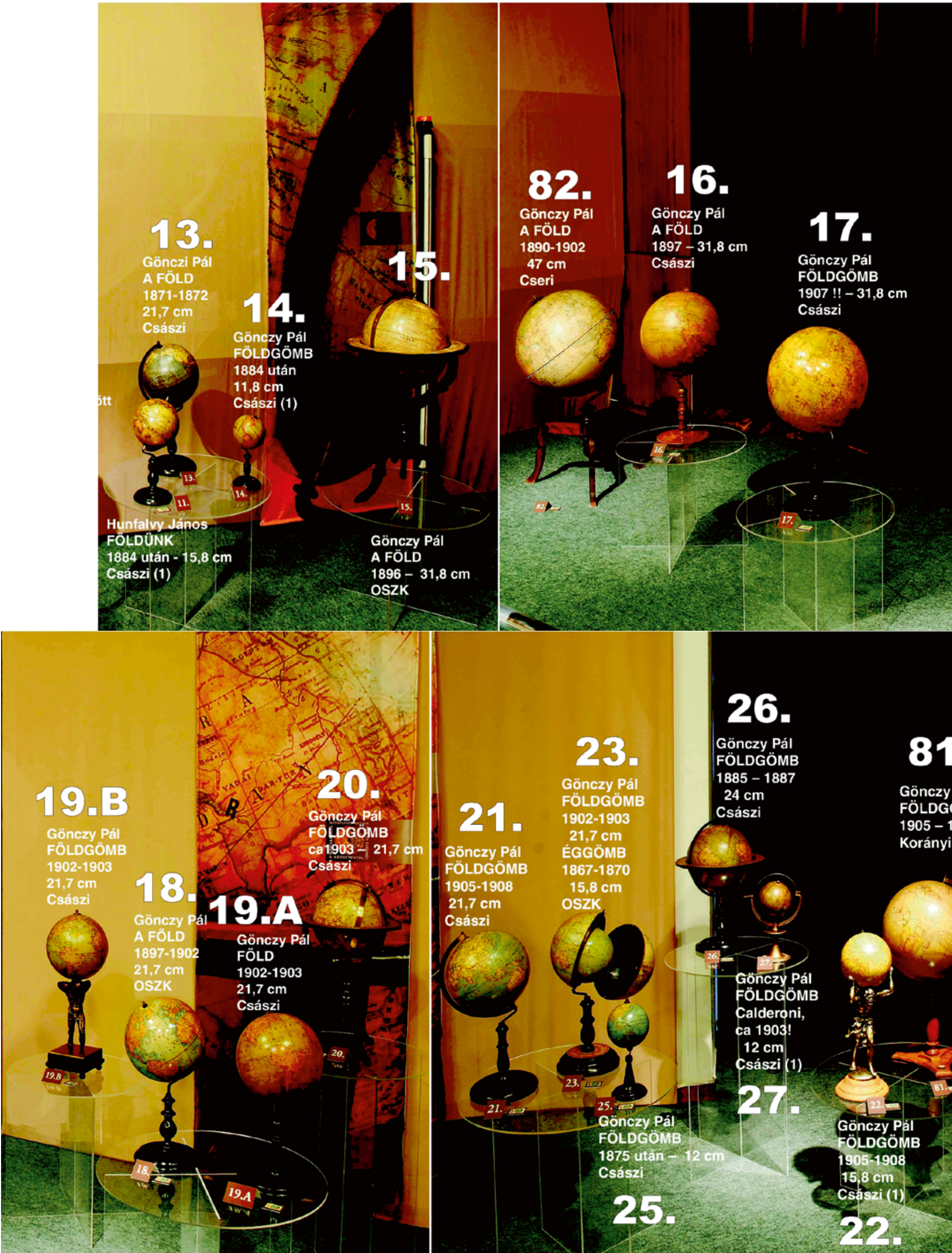

\section{6.}

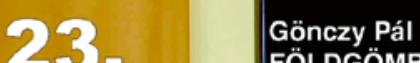

FÖLDGÖMB

$1885-1887$

Gönczy Pál

FÖLDGÖMB

$24 \mathrm{~cm}$

Császi

$21,7 \mathrm{~cm}$
ÉGGOMB

1867-1870

$15,8 \mathrm{~cm}$

oszK

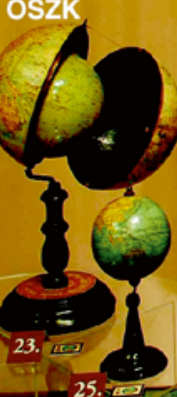

25.

FÖLDGOMB

1875 utan

Császi
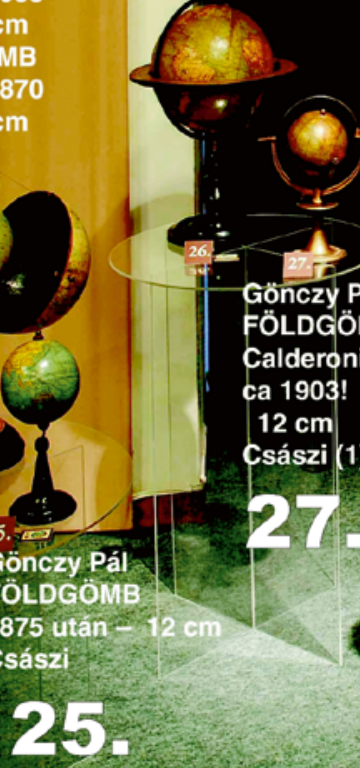

Calderoni,

ca 1903 !

$12 \mathrm{~cm}$

Császi (1)

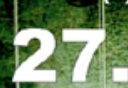

\section{1.}

Gönczy Pál

FÖLDGÖMB

$1905-1908-33 \mathrm{~cm}$ Korányi

Gơnczy Pál

FöLDGÖMB

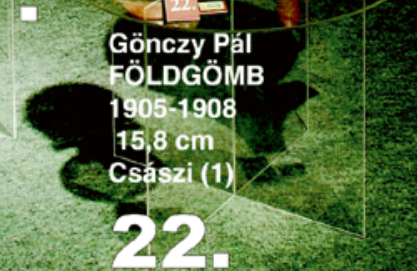

1. ábra. A Gönczy Pál által magyarított Felkl-(13-15., 82.,16-23.) és Schotte-glóbuszok (25-27., 81.) az OSZK kiállításán (Kurátor: Plihál Katalin) (Fotók: Nemes Zoltán) 
útvonalakkal és transzkontinentális vasútvonalakkal. A kezdômeridián greenwichi, jó állásban megrajzolt Ekliptika jellemzi. Kolofon: „FÖLDGÖMB | Magvarúl (!) szerkesztette | Gönczy Pál" (VGM ID 101; 1. ábra. 19 A kép; Plihál p. 111. 2. leirás, p. 112. „1894 után” feliratú kép).

\section{$21,7 \mathrm{~cm}\left(8 \% \frac{1}{4}\right.$ bécsi}

hüvelyk) átmérójú,

1:58733000 méretarányú domborzati-politikai földgömb. Egyenlítôi kerülete: $68,23 \mathrm{~cm}$.

Országhatárbandos, lejtốcsíkozásos domborzatrajzú, politikai tartalma (országábrázolása) szerint 1897-1902 között készített glóbusz, párhuzamos vonalfonatokkal jelölt tengeráramlásokkal és nyilakkal jelölt áramlásirányokkal, tengermélységadatokkal, hajózási útvonalakkal és transzkontinentális vasútvonalakkal. Ferrói kezdốmeridián (!), fordított állásban megrajzolt Ekliptika jellemzi. Sajátos tengerpart menti vízszintes sraffozás, amely sötétebb „kerettel” kiemeli a szárazföldi partvonalat. Egyértelmúen különbözô idôkbôl származó gömbszegmensekbôl „összerakott” munka, amit a szomszédos szelvényeken átmenô nevek hiánya is mutat (pl. a déli szélesség $10^{\circ}$ és $20^{\circ}$ között: „toi (!) déli folyás” elsố része a kezdômeridián Ny-i oldalán az „Egyenlî” lenne). Kolofon: „A | FÖLD | a legújabb felfedezések nyomán | Magyarúl szerkesztette | Gönczy Pál | a m. kir. közoktatási minister megrendeléseböl (!) | Kiadta Felkl és fia | Rozstok, Pragam" (VGM ID 97; 1. ábra. 18. kép; Plihál p. 110. 3. leírás, p. 112. „1884 után” feliratú kép).

\section{$21,7 \mathrm{~cm}\left(8 \frac{1}{4}\right.$ bécsi}

\section{hüvelyk) átmérôjú,}

1 :58 733000 méretarányú domborzati-politikai földgömb. Egyenlítô $i$ kerülete: $68,23 \mathrm{~cm}$.

Országhatárbandos, lejtốcsíkozásos domborzatrajzú, 1903-ban kiadott glóbusz, párhuzamos vonalfonatokkal jelölt tengeráramlás-ábrázolással és nyilakkal jelölt áramlásirányokkal, tengermélységadatokkal, hajózási útvonalakkal és transzkontinentális vasútvonalakkal. A kezdômeridián greenwichi, jó állásban megrajzolt Ekliptika jellemzi. Kolofon: „FÖLDGÖMB | a legújabb felfedezések nyomán । Magvarúl (!) szerkesztette | Gönczy Pál | a m. kir. közoktatási minister megrendeléseböl (!). | Kiadta | Felk1 J. és fia" (VGM ID 106; 1. ábra. 19 B kép; Plihál p. 111. 1. leirás, p. 112. „1891 után, de 1894 elôtt” feliratú kép).7

\section{$21,7 \mathrm{~cm}\left(8^{1 / 4}\right.$ bécsi}

hüvelyk) átmérôjuú,

1:58733000 méretarányú domborzati-politikai földgömb. Egyenlítôi kerülete: $68,23 \mathrm{~cm}$.

Országhatárbandos, lejtốcsíkozásos domborzatrajzú, 1903-ban kiadott glóbusz, párhuzamos vonalfonatokkal jelölt tengeráramlás-ábrázolással és nyilakkal jelölt áramlásirányokkal, tengermélységadatokkal, hajózási útvonalakkal és transzkontinentális vasútvonalakkal. A kezdômeridián greenwichi, jó állásban megrajzolt Ekliptika jellemzi. Kolofon: „FÖLDGÖMB | a legújabb felfedezések nyomán | Magvarúl (!) szerkesztette Gönczy Pál | a m. kir. közoktatási minister megrendeléseböl (!). | Kiadta | Felk1 J. és fia”. Kombinált földés éggömbmodell külsô, kinyitható földgömbrésze. Az egybeépített glóbuszpár különlegessége, hogy a szétnyitható, $21,7 \mathrm{~cm}$ átmérôjú földgömb a belsejében rejt egy ugyanazon tengelyen forgatható $15,8 \mathrm{~cm}$-es éggömböt. A földgömb egy rugós gomb megnyomásával szétnyitható két féltekére, így válik láthatóvá a belsejében lévô éggömb. Kinyitott állapotban a földgömb a tengelyrôl leemelhetô, és a belsejében található két kifordítható fémkampó segítségével a kinyitott gömb felakasztható az iskolákban használt táblára (VGM ID 108; 1. ábra. 23. kép; Plihál p. 110. 4. leírás, p. 112. „1885 után, de 1890 elôtt" feliratú kép).

\footnotetext{
7 Plihál leírása a 111. oldalon és a hivatkozott térkép a 112.-en megfelelnek egymásnak és a VGM ID 106-os 3D-s glóbusznodellnek is. Így azonban nyilvánvaló elírás a bevezetố mondatban „A FÖLD”, amely helyesen FÖLDGÖMB", és téves az évszámmegjelölés is, ami helyesen a gömbtartalom alapján 1903.
}

$31,6 \mathrm{~cm}$ (12 bécsi hüvelyk) átmérơjú,

1 : 40379000 méretarányú politikai-domborzati földgömb. Egyenlítôi kerülete: 99, $25 \mathrm{~cm}$.

Országhatárbandos, lejtốcsíkozásos domborzatrajzú, 1896-ban kiadott glóbusz, párhuzamos vonalfonatokkal jelölt tengeráramlásokkal, áramlásnevekkel és nyilakkal jelölt áramlásirányokkal, hajózási útvonalakkal. Ferrói kezdőmeridián (!), fordított állásban megrajzolt Ekliptika jellemzi. Kolofon: „A FÖLD | magyarul szerkesztette GÖNCZY PÁL a m kir közoktatasugyı (!) | minister megrendeleséböl (!) | kiadta FELKL J. ÉS FIA | ROZTOKON PRAGA MELLETT” és „A budapesti 1896 | évi | milleniumi kiállítás | $\mathrm{s}$ a magyar államnak | ezer évi | fennállása | emlékéül." (VGM ID 100; 1. ábra. 15. kép; Plihál p. 115. 1. leírás, p. 116. „1896 után” feliratú kép).

\section{$31,6 \mathrm{~cm}$ (12 bécsi}

\section{hüvelyk) átmérójú,}

1 : 40379000 méretarányú politikai-domborzati földgömb. Egyenlitố $i$ kerülete: $99,25 \mathrm{~cm}$.

Országhatárbandos, lejtôcsíkozásos domborzatrajzú, 1897-ben kiadott glóbusz, párhuzamos vonalfonatokkal jelölt tengeráramlás-ábrázolással, áramlásnevekkel és nyilakkal jelölt áramlásirányokkal, hajózási útvonalakkal. Ferrói kezdômeridián (!), fordított állásban megrajzolt Ekliptika jellemzi. Kolofon: „A FÖLD | magyarul szerkesztette GÖNCZY PÁL a m kir közoktatásügyí (!) | minister megrendeléséböl (!) | kiadta FELKL J. ÉS FIA | ROZTOK PRÁGA MELLETT | Második javított kiadás. 1897. | Atvizsgálta (!) Berecz Ántal. (!)” (VGM ID 105; 1. ábra. 16. kép; Plihál p. 115. 2. leírás, p. 116. „1897”feliratú kép).

\section{1,6 cm (12 bécsi} hüvelyk) átmérôjú, 1 : 40379000 méretarányú politikai-domborzati földgömb. Egyenlitói $i$ kerülete: 99,25 cm.

Országhatárbandos, lejtôcsíkozásos domborzatrajzú, $1907^{8}$-ben kiadott glóbusz, párhuzamos vonalfonatokkal

\footnotetext{
8 A glóbusz politikai tartalma alapján meg adott kiadási év. Nem egyezik a kolofonban szereplố évszámmal!
} 
jelölt, rajzos tengeráramlás-ábrázolással, áramlásnevekkel és nyilakkal jelölt áramlásirányokkal, hajózási útvonalakkal. Ferrói kezdőmeridián (!), fordított állásban megrajzolt Ekliptika jellemzi. Kolofon: „A FÖLD | magyarul szerkesztette GÖNCZY PÁL a m kir közoktatásügyí (!) | minister megrendeléséböl (!) | kiadta FELKL J. ÉS FIA | ROZTOK PRÁGA MELLETT | Második javított kiadás. 1897. | Atvizsgálta (!) Berecz Antal." (A VGM-ben nem szerepel!; 1. ábra. 17. kép; Plihál p. 115. 3. leirás).

\section{7,4 cm (18 bécsi}

hüvelyk) átmérójú,

1 : 26919000 méretarányú domborzati-politikai földgömb. Egyenlitối kerülete: $148,87 \mathrm{~cm}$.

Lejtôcsíkozásos domborzatrajzú, határbandos országábrázolású, 1870ben kiadott földgömb, az élénk középkék színú tengerfelületben negatív rajzolatú (fehér) párhuzamos vonalfonatokkal jelölt tengeráramlás-ábrázolással, áramlásnevekkel, tengermélység-adatokkal, valamint „táviró huzal" nyomvonalakkal és kikötôtôl kikötôig megírt, sorszámozott hajózási útvonalakkal, távolságmegjelöléssel. Ferrói kezdômeridián, fordított állásban megrajzolt Ekliptika (!) jellemzi. Közel egykorú kiadású a VGM ID 149 jelü földgömbbel, de az északi pólussapka tartalma és rajzolata alapján ez a régebbi! Ezt erốsíti a tengeráramlás-ábrázolás stílusa is! Kolofon: „A | FÖLD | magyarul szerkesztette | Gönczy Pál | a m. kir. közoktatásügyi minister megrendeléséböl (!) | kiadta | FELKL JÁNOS | PRÁGÁBAN | -x- | Köre metszette és nyomatta (!) | H. KUNSCH. | LIPCSÉBEN." (VGM ID 137; Az OSZK kiállitáson nem szerepelt!; Plihálp. 117. 1. leírás).

Mivel ez a glóbusz nem szerepelt az OSZK-ban 2010-2011-ben megrendezett kiállításon, közlünk képeket róla (2. ábra).

\section{7,4 cm (18 bécsi}

hüvelyk) átmérôjứ,

1 : 26919000 méretarányú domborzati-politikai földgömb. Egyenlitối kerülete: $148,87 \mathrm{~cm}$.

Kezdetleges hipszometrikus színezésú és lejtőcsíkozásos domborzat- rajzú, valamint határbandos országábrázolású, 1888-ban vagy az után kiadott földgömb, párhuzamos vonalfonatokkal jelölt tengeráramlás-ábrázolással, áramlásnevekkel, tengermélységadatokkal, valamint „táviró huzal” nyomvonalakkal és kikötôtôl kikötőig megírt, sorszámozott hajózási útvonalakkal, távolságmegjelöléssel. Ferrói kezdőmeridián (!), fordított állásban megrajzolt Ekliptika (!) jellemzi. Kolofon: „A | FÖLD | magyarul szerkesztette | Gönczy Pál | a m. kir. közoktatásügyi minister megrendeléséböl (!) | kiadta | FELKL J. ÉS FIA | Roztok Prága mellett" (VGM ID 98; 1. ábra. 82. kép; Plihál p. 117. 2. leírás).

\section{A Schotte-Gönczy- glóbuszok}

A 2007-ben alapított VGM és a 20102011-es OSZK-kiállítás mindösszesen négy példányát tudta felsorakoztatni ezeknek a földgömböknek. Ez a szám bôvül, ahogy azt a késóbbiekben látjuk majd.

\section{$11,9 \mathrm{~cm}\left(4^{1 / 2}\right.$ bécsi} hüvelyk) átmérôjuú,

1 : 107677000 méretarányú domborzati (politikai) földgömb. Egyenlítői kerülete: $37,22 \mathrm{~cm}$.

Kontinensszínezéses (band nélküli felületi színezésû), lejtőcsíkozásos domborzatrajzú, 1872-ben kiadott glóbusz országnevekkel, jellemzôen csak a gyarmati határrajzzal (pl. Afrika, Ausztrália), egyébként országhatárok nélkül. A kezdômeridián ferrói, jó állásban megrajzolt Ekliptika jellemzi. Kolofon: „A legujabb és legjobb forrá | sok szerint készitett | FỐLDGÖMB | magyaritotta | Gönczy-Pál | kiadja | Schotte Ernö es tarsa | BERLINBEN". (VGM ID 56; 1. ábra 25. kép; Plihál p. 128. 2. leírás).

\section{$11,9 \mathrm{~cm}\left(4^{1} \frac{1}{2}\right.$ bécsi} hüvelyk) átmérôjú,

1 : 107677000 méretarányú domborzati (politikai) földgömb. Egyenlítối kerülete: $37,22 \mathrm{~cm}$.

Kontinensszínezéses (band nélküli felületi színezésû), lejtôcsíkozásos domborzatrajzú, 1872-ben
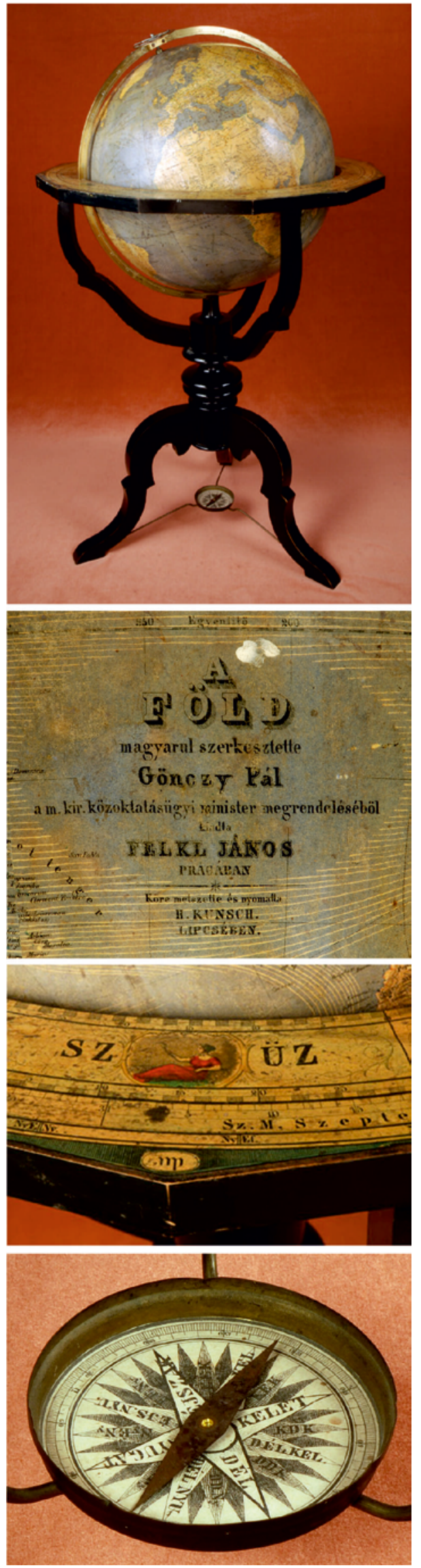

2. ábra. A 47,4 cm-es földgömb a Kalocsai Fốszékesegyházi Könyvtárban Fischerné Grócz Zita szivességébôl. Fotók: Nemes Zoltán 
kiadott glóbusz országnevekkel, jellemzôen csak a gyarmati határrajzzal (pl. Afrika, Ausztrália), egyébként országhatárok nélkül. A kezdőmeridián ferrói, jó állásban megrajzolt Ekliptika jellemzi. Kolofon: „A legujabb és legjobb forrá | sok szerint készitett | FỐLDGÖMB | magyaritotta | Gönczy-Pál | kiadja | Schotte Ernö es tarsa | BERLINBEN". A Calderoni és Társa által gyártott és forgalmazott Csaszny Valér-féle „Aristarchos” tellurium-lunáriumba beépítve. ( $A$ VGM-ben nem szerepel!; 1. ábra 27. kép-Calderoni-taneszköz; Plihál p. 135.).

\section{3,7 cm (9 bécsi}

\section{hüvelyk) átmérôjú,}

1 :53 839000 méretarányú politikai-domborzatiföldgömb. Egyenlitối kerülete: $74,44 \mathrm{~cm}$.

Színes országhatárbandos, lejtőcsíkozásos domborzatrajzú, 1885-1887 között kiadott földgömb, párhuzamos vonalfonatokkal jelölt tengeráramlás-ábrázolással, áramlásnevekkel, az áramlásirányt mutató nyilakkal. Ferrói kezdômeridián (!), jó állásban megrajzolt Ekliptika jellemzi. Kolofon: „A legujabb (!) és legjobb forrá (!) | sok szerint készitett (!) | FỐLDGÖMB (!) | magyaritotta (!) | Gönczy Pál | kiadja | Schotte Ernö (!) és társa | BERLINBEN." (VGM ID 99; 1. ábra 26. kép; Plihál p. 129. 2. leírás).

\section{$32,9 \mathrm{~cm}\left(12^{1 / 2}\right.$ bécsi}

\section{hüvelyk) átmérôjú,}

1 : 38764000 méretarányú politikai-domborzatiföldgömb. Egyenlitő $i$ kerülete: $103,38 \mathrm{~cm}$.

Színes országhatárbandos, lejtốcsíkozásos domborzatrajzú, 1905-1908 között kiadott földgömb, párhuzamos vonalfonatokkal jelölt tengeráramlás-ábrázolással, áramlásnevekkel, az áramlásirányt mutató nyilakkal. Ferrói kezdômeridián (!), jó állásban megrajzolt Ekliptika jellemzi. Kolofon: „A legujabb és legjobb forrá | sok szerint készitett | FÔLDGÖMB | magyaritotta | Gönczy Pál | kiadja | Schotte Ernö és társa | BERLINBEN." (VGM ID 107; 1. ábra 81. kép; Plihál p. 129. 3. leírás).
Cikksorozatunk következô részében új, utóbb felfedezett, illetve megújuló Gönczy-földgömbökkel foglalkozunk.

\section{Irodalom}

Ambrus-Fallenbüchl Zoltán 1964. Ungarische Globenmacher der Vergangenheit Der Globusfreund, Publ. Nr. 13., Wien p. 78

Fodor Ferenc 1952-1954. A magyar térképírás (I-III. kötet) Honvéd Térképészeti Intézet, Budapest, p. 441

Fodor Ferenc 2006. A magyar földrajztudomány története MTA Földrajztudományi Kutatóintézet, Budapest, p. 820

Füsi Lajos 1966. Az elsố magyar dombormúvú múanyag földgömb Technológiai és kartográfiai elvek és módszerek. Doktori értekezés, Budapest

Gönczy Pál 1871. Utasítás a földgömb ismertetésére és használatára népiskolai tanítók számára. Pesten. Kiadja Ráth Mór. p. 80

Gönczy Pál 1872. Utasítás a földgömb és a tellurium ismertetésére és használatára népiskolai tanítók számára (2. bővített kiadás) Pest.p. 108.

Horváth Gergely 1986. Gönczy Pál kartográfiai munkássága Geodézia és Kartográfia, 38. évf., 5. szám, pp. 363-368.

Irmédi-Molnár László 1971. Térképalkotás. Tankönyvkiadó, Budapest, p. 495.

Klinghammer István 1969. A magyar földgömbkészítés történetébôl. Geodézia és Kartográfia, 21. évf., 3. szám, pp. 208-211.

Klinghammer István 1973. A magyar földgömbkészítés történetéből. Térképtudományi Tanulmányok (Studia Cartologica), 4. kötet, Budapest, pp. 37-48.

Klinghammer István 1998. A föld- és éggömbök története Eötvös Kiadó, Budapest, p. 104

Klinghammer István 2002. A földrajzi szemléltetés korai története. Geodézia és Kartográfia, 54. évf., 12. szám, pp. 8-14.

Klinghammer István 2017. Föld- és éggömb - az oktatás eszköze, a lakás dísze. Magyar Tudomány 178. évf., 3. szám, pp. 377-379.

Lovizer Lilla 2013. A prágai Felkl cég glóbuszai a 19. századi magyar földrajzoktatásban. Geodézia és Kartográfia, 65. évf., 3-4. szám, pp. 18-21.

Márton Mátyás - Plihál Katalin 2010. Magyar föld- és éggömbök. Két évszázad éggömbjei az Országos Széchényi Könyvtár kiállításán Geodézia és Kartográfia, 62. évf., 9. szám, pp. 13-24.

Novotná, Eva 2017. Jan Felkl \& syn továrna na glóby / Jan Felk1 \& Son a GlobeMaking Factory. Univerzita Karlova, Prirodovedecká Fakulta, Praha, p. 184

Papp-Váry Árpád 1983. Földgömbök, éggömbök, bolygóglóbusok. In Klinghammer István-Papp-Váry Árpád: Földünk tükre a térkép. Gondolat, Budapest, p. 386

Papp-Váry Árpád 2007. Térképtudomány. A pálcikatérképtől az û́rtérképig Kossuth Kiadó, Budapest, p. 464
Papp-Váry Árpád 2013. Ernst Schotte magyar nyelvú földgömbjei és dombortérképei Geodézia és Kartográfia, 65. évf., 9-10. szám, pp. 9-11.

Patay Pálné 1984. Az Országos Széchényi Könyvtár térképtárának újabb szerzeménye: egy Felkl-Gönczy féle kombinált glóbus. Geodézia és Kartográfia, 36. évf., 6. szám, pp. 457-458.

Plihál Katalin (kurátor) 2010-2011. Nyomtatott magyar föld- és éggömbök a kezdetektől napjainkig Kiállítás, Országos Széchényi Könyvtár, Budapest

Plihál Katalin 2016. Nyomtatott magyar földés éggömbök 1840-1990 Zrínyi Kiadó, Budapest, p. 232

Stegena Lajos 1980. Térképtörténet. Tankönyvkiadó, Budapest, p. 198

Szinnyei József 1894. Magyar írók élete és munkái, 3. kötet. Gönczy Pál $p p$. 1360-1367. Hornyánszky Viktor, Budapest, p. 1582

Virtuális Glóbuszok Múzeuma 2007- ELTE Térképtudományi és Geoinformatikai Intézet, Budapest

http://terkeptar.elte.hu/vgm vagy http://vgm.elte. $h u$

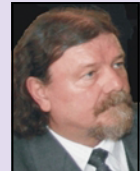

Dr. Márton Mátyás professor emeritus

ELTE Térképtudományi és Geoinformatikai Intézet matyi@map.elte.hu

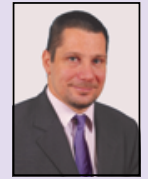

\section{Dr. Toronyi Bence adjunktus}

Budapesti Múszaki és Gazdaságtudományi Egyetem, Építőmérnöki Kar, Általános és Felsôgeodézia Tanszék toronyi.bence@emk.bme.hu 